mixed with the supposed 11-hydroxytetrahydrocarbazolenine.

Dyson Perrins Laboratory,
S. G. P. Plant

R. ROBINSON
University, Oxford.

Nov. 15.

Bucherer and Grolée, Ber. deut. chem. Ges., 39, 99l (1906).

- Plancher and Bettinalli, Gazetta, 29, 1, 115 (1899).

${ }^{3}$ Betts, Muspratt and Plant, J. Chem. Soc., 1311 (1927).

- Perkin and Plant, $J$. Chem. Soc., 123, 676 (1923).

- Blount, Perkin and Plant, J. Chem. Soc., 1975 (1929).

- Beer, McGrath, Robertson and Woodier, Nature, 164, 363 (1949).

\section{A Yellow Pigment Formed from Para- Aminobenzoic Acid and Para-Aminosalicylic Acid by Various Strains of Mycobacterium}

We have previously shown that para-aminobenzoic acid is transformed into a yellow pigment by various species of mycobacteria ${ }^{1,2,3}$. The chemical com. position of this pigment is unknown; but it has been established as an oxidation product of para-aminobenzoic acid. The pigment is insoluble in water and in most of the usual organic solvents, but is very soluble in phenol and glacial acetic acid. Various substances related to para-aminobenzoic acid, with the exception of procaine, were unable to form this pigment.

We have found, as with para-aminobenzoic acid, that para-aminosalicylic acid is transformed into a yellow pigment by Mycobacterium smegmatis and the closely related strain, Mycobacterium tuberculosis var. hominis No. 607, both of which organisms are naturally resistant to para-aminosalicylic acid. The conditions under which the para-aminosalicylic acid pigment is formed closely resemble those described for the formation of para-aminobenzoic acid pigment. It is noteworthy that replacement of glycerol by glucose strongly inhibits the formation of the pigment. In the presence of para-aminobenzoic acid, the biosynthesis of riboflavin by mycobacteria ${ }^{4}$ is more rapid and the amount formed appreciably increased. Para-aminosalicylic acid has the same influence as para-aminobenzoic acid on the production of riboflavin.

Para-aminosalicylic acid pigment differs from the para-aminobenzoic acid pigment in several respects : (1) its colour is more reddish ; (2) it is partially soluble in water and especially soluble in diluted acids and

Pigment production by Mycobacterium smegmatis

\begin{tabular}{|c|c|c|}
\hline Pigment produced & $\begin{array}{l}\text { Colour of } \\
\text { pigment }\end{array}$ & No pigment produced \\
\hline $\begin{array}{l}P a r a-a m i n o b e n z o i c \\
\text { acid }\end{array}$ & Yellow & $\begin{array}{l}\text { In addition to substances } \\
\text { already mentioned }\end{array}$ \\
\hline Acetyl para-amino- & Yellow & $o-$ and $m$-Áminobenzoic \\
\hline $\begin{array}{l}\text { Para-aminobenzoyl- } \\
\text { diethyl-amino- } \\
\text { ethanol (procaine) }\end{array}$ & Yellow & $\begin{array}{l}m \text {-and } p \text {-Hydroxybenzoic } \\
\text { acid }\end{array}$ \\
\hline $\begin{array}{l}\text { Para-aminosalicylic } \\
\text { acid }\end{array}$ & Orange-yellow & $o$-Hydroxybenzyl alcohol \\
\hline $\begin{array}{l}\text { Para-nitrobenzoic } \\
\text { acid }\end{array}$ & & $\begin{array}{l}\text { 2,4-Dihydroxybenzoic } \\
\text { acid }\end{array}$ \\
\hline $\begin{array}{l}3,5 \text { Dinitrobenzoic } \\
\text { acid }\end{array}$ & & $o-\underset{\text { and }}{\text { amine }} m$-Phenylenedi- \\
\hline $\begin{array}{l}\text { 3,5 Dinitrosalicylic } \\
\text { acid }\end{array}$ & Orange-yellow & m-Aminophenol \\
\hline Folic acid & Orange & $\begin{array}{l}\text { 2,4-Diaminophenol } \\
\text { Acetyl derivatives of o-, } \\
m \text { - and } p \text {-toluidine } \\
2,4,6 \text {-Triaminotoluene } \\
\text { and 5-Nitrosalicylic } \\
\text { acid }\end{array}$ \\
\hline
\end{tabular}

alkali; (3) it is much less stable than paraaminobenzoic acid pigment. The colour of the pigment rapidly changes to a dark brown within the first few days of growth.

In the accompanying table are named a number of substances capable or incapable of pigment formation.

A great number of related substances had definite antibacterial activities. The following substances were bacteriostatic in concentrations of 0.025 per cent or greater : 3,4-diaminotoluene, 2,5-diaminotoluene, 2,4-diaminotoluene, catechol, resorcinol, para-phenylenediamine, $o$ - and $p$-aminophenol, $1,2,4$ triaminobenzene, $p$-aminoacetophenone.

In the presence of salicylic acid and acetyl salicylic acid, another pigment is produced which differs from the para-aminobenzoic acid pigment, as seen from its behaviour to fluorescent light.

R. L. MAYER

Carol Crane

Research Laboratories,

Ciba Pharmaceutical Products, Inc.,

Summit, New Jersey. Aug. 5.

${ }^{1}$ Mayer, R. L., Science, 98, 2539 (1943).

Mayer, R. L., J. Bact., 48, 337 (1944).

${ }^{3}$ Mayer, R. L., J. Bact., 48, 93 (1944).

‘ Mayer, R. L., and Rodbart, M., Arch. Biochem., 11, 49 (1946)

\section{Solar Noise and lonospheric Fading}

A STUDY of the correlation between the occurrence of bursts of solar noise and anomalies in ionospheric wave propagation was initiated at the Radio Research Station, Slough, by Mr. R. E. Burgess in 1948 and continued during that year by Messis. C. S. Fowler and R. W. Mason. Some interesting effects on radio transmissions in the low-frequency band at times of sudden ionospheric disturbances have been observed.

In the course of this work simultaneous recordings were made of the relative intensity of solar noise at frequencies of $30,42,73$ and $155 \mathrm{Mc}$./s. and of the strength of signals from the stations of Klipheuvel, South Africa, on 18.89 Mc./s., and Königswusterhausen, Germany, on $191 \mathrm{kc} / \mathrm{s}$. On a number of occasions a burst of noise was accompanied by a complete fade-out (of the Dellinger type) of the highfrequency signal and a marked fluctuation in the level of the low-frequency signal. The most outstanding example occurred at about 1130 G.M.T. on May 21, 1948, at the time of a large solar flare which has already been reported ${ }^{1}$. The records for the two stations and for the noise on $30 \mathrm{Mc} / \mathrm{s}$. are reproduced in the accompanying figure.

The main feature of the record to which $\mathrm{I}$ wish to direct attention is the variation of the low-frequency signal during the fade-out. As pointed out by Dr. B. G. Pressey, the nature of this variation is characteristic of interference between the ground and ionospheric waves caused by a change in the phase and amplitude of the ionospheric wave; and this could be explained by a change in the equivalent height of reflexion together with an increase in the effective reflexion coefficient of the ionosphere. Normally the intensity of the ionospheric wave from a low-frequency station at this distance $(975 \mathrm{~km}$.) is relatively small at noon; but the record shows a considerable increase of intensity over a period of ten minutes which is approximately the same as the duration of the noise burst. The relative phasechange during the disturbed period is seen to be about two cycles, which corresponds to a change in equivalent height of reflexion of about $10 \mathrm{~km}$., if a 